\title{
Intestinal Maturation: Characterization of Mitochondrial Calcium Transport in the Rat
}

\author{
TOSHIKO KIKUCHI, ${ }^{1}$ KAZUHIRO KIKUCHI, ${ }^{1}$ NOUSHIN ARAB, AND FAYEZ K. GHISHAN \\ Vanderbilt University School of Medicine, Department of Pediatrics, Division of Gastroenterology and Nutrition, \\ Nashville, Tennessee 37232
}

\begin{abstract}
The mitochondria play a major role in the regulation of intracellular calcium. Despite the fact that the enterocytes receive the majority of absorbed calcium, the role of the intestinal mitochondria in calcium transport during maturation is not known. Therefore, the current studies were designed to characterize calcium pump activity of jejunal mitochondria of rats during maturation (suckling, weanling, and adolescent rats). The functional integrity of the intestinal mitochondria of suckling and adolescent rats was determined by oxygen consumption studies demonstrating respiratory control ratios of more than 3 when succinate was used as a test substrate. $\mathrm{Ca}^{++}$uptake was significantly stimulated by the presence of $3 \mathrm{mM}$ ATP at all age groups studied. Maximal $\mathrm{Ca}^{++}$uptake in the presence of $3 \mathrm{mM}$ ATP and $2 \mathrm{mM}$ succinate was $31.1 \pm$ $0.4,50.2 \pm 4.2$, and $94.3 \pm 1.5 \mathrm{nmol} / \mathrm{mg}$ protein (mean \pm SE) in suckling, weanling, and adolescent rats, respectively. Rates of ATP hydrolysis were 15.5 \pm 1.5 and $2.9 \pm$ $0.3 \mathrm{nmol} / \mathrm{ATP}$ hydrolyzed/mg protein in adolescent and suckling rats, respectively $(p<0.001) . \mathrm{Ca}^{++}$uptake was completely inhibited by $0.25 \mu \mathrm{M}$ ruthenium red, oligomycin (10 $\mu \mathrm{g} / \mathrm{mg}$ protein), $0.5 \mathrm{mM}$ dinitrophenol and $1 \mathrm{mM}$ sodium azide at all age groups. $\mathrm{Ca}^{++}$efflux in the presence of ruthenium red occurred by a $\mathrm{Na}^{+}$-dependent pathway, indicating a $\mathrm{Ca}^{++} / \mathrm{Na}^{+}$exchange mechanism. Kinetic parameters for ATP stimulated $\mathrm{Ca}^{++}$uptake at $10 \mathrm{~s}$ revealed a $\mathrm{Km}$ of $0.84 \pm 0.11,0.65 \pm 0.17$, and $0.57 \pm 0.03 \mu \mathrm{M}$ and $V_{\max }$ of $1.83 \pm 0.07,3.62 \pm 0.26$ and $14.15 \pm 0.21$ $\mathrm{nmol} / \mathrm{mg}$ protein $/ 10 \mathrm{~s}$ in suckling, weanling, and adolescent rats, respectively. These results indicate that the mitochondria of the suckling enterocyte possess a well-characterized calcium transport system; however, the affinity and capacity of the transport system increases with advancing age. The greater capacity seen with increasing age most likely reflects greater rates of ATP hydrolysis in adolescent rats compared to suckling rats, thus providing greater driving force for calcium uptake. (Pediatr Res 25:107-113, 1989)
\end{abstract}

\section{Abbreviations}

DEAE-cellulose, diethylaminoethyl-cellulose

FCCP, carbonyl cyanide $p$ trifluoromethoxyphenylhydrazone

PMSF, phenylmethylsulfonyl fluoride

p-MB, p-chloromercuribenzoic acid

Received April 18, 1988; accepted September 15, 1988

Correspondence Fayez K. Ghishan, M.D., Vanderbilt University School of Medicine, Department of Pediatrics, Division of Gastroenterology/Nutrition, D4130 MCN, Nashville, TN 37232.

Supported by NIH 2RO1 DK33209 04.

${ }^{1}$ Present address Department of Medicine, School of Medicine, Tokai University, Boseidai, Isehara, Kanagawa, 259-11 Japan.
The mitochondria occupy a substantial fraction of the cytoplasm of virtually all eucaryotic cells and their role in oxidative metabolism is well established (1-4). Calcium transport by the mitochondria represents a highly specialized process involved in relaying changes in cytosolic calcium to the inner mitochondrial membrane and acts as a buffer system within the cytoplasm. This specialized calcium transport system by mitochondria has been well characterized for such organs as the heart and liver and for muscle (1-4). Current evidence suggests that when the cytoplasmic concentration of calcium is increased by hormones, the intramitochondrial concentration increases, resulting in activation of several enzymes such as pyruvate dehydrogenase and oxoglutarate dehydrogenase. The increase in cytosolic calcium concentration by hormones occurs by release from the endoplasmic reticulum stores through the action of inositol triphosphate (1-4).

But, despite the fact that the intestinal epithelial cell receives the majority of absorbed $\mathrm{Ca}^{++}$, the role of the intestinal mitochondrial $\mathrm{Ca}^{++}$transport has received little attention $(5,6)$. Furthermore, to our knowledge, the developmental characteristics of the intestinal mitochondrial transport system is entirely unknown.

Until recently, the preparation of enterocyte mitochondria was difficult because the small intestine of rats contains a large number of goblet cells (7) which secrete mucus, thus complicating the isolation of intestinal mitochondria.

In the present study, rat jejunal mitochondria were obtained using DEAE-cellulose, which completely binds and removes the intestinal mucus. This method was adapted from that of Lawrence and Davies (8).

The present studies characterize for the first time intestinal mitochondrial $\mathrm{Ca}^{++}$influx and efflux during maturation. A millipore filtration technique was used to study mitochondrial calcium fluxes $(1,3,9)$.

\section{MATERIALS AND METHODS}

Animals. Two male adolescent rats (42 days old), 8-10 weanling rats ( 21 days old), and 8-10 suckling rats ( 15 days old) of the Sprague-Dawley strain were used for each experiment. Rats were obtained from Harlan Laboratories (Indianapolis, IN). Adolescent and weanling rats were fed a standard diet (Teklad Diets, Madison, WI). Suckling rats were allowed to suckle mothers' milk freely.

Materials. DEAE-cellulose and other reagents and biochemicals were purchased from Sigma Chemical Corp. (St. Louis, MO), Fisher Scientific (Norcross, GA), or Aldrich Chemical Company (Milwaukee, WI). Nylon cloths for the filtration of mucosal samples were obtained from general nylon goods. ${ }^{45} \mathrm{Ca}$ $(10-40 \mathrm{mCi} / \mathrm{mg})$ and ${ }^{3} \mathrm{H}$-sucrose $(44 \mathrm{mCi} / \mathrm{mg})$ were obtained from Amersham Corp. (Arlington Heights, IL). Cellulose nitrate filters, $0.45-\mu \mathrm{m}$ pore size, were obtained from Sartorius Filters, Inc. (Hayward, CA). 
Preparation of mitochondria. Rat jejunal mitochondria were prepared by slight modifications of the method of Lawrence and Davies (8), in which an anion exchange cellulose (DEAE-cellulose) was used to remove adherent mucus.

After obtaining adequate anesthesia with intraperitoneal injection of pentobarbital $(200 \mathrm{mg} / \mathrm{kg})$, the abdominal cavity was opened. The jejunal segment was isolated, cannulated, and then flushed out with ice-cold "gut wash" containing: $160 \mathrm{mM}$ sucrose, $110 \mathrm{mM}$ mannitol, $2 \mathrm{mM}$ HEPES, $3.3 \mathrm{mM}$ tris, $0.25 \mathrm{mM}$ EGTA, 0.1 mM PMSF, pH 7.4, which was oxygenated with $100 \% \mathrm{O}_{2}$ for at least $30 \mathrm{~min}$ before use in situ.

The jejunum was then removed and placed in the same medium "gut wash." The jejunum was then everted and dried by filter paper. Mucosal scrapings were obtained by glass slides on a cooled glass plate. The amount of mucosal scrapings obtained was $2.5-3 \mathrm{~g}$ for two adolescent rats, $2-2.5 \mathrm{~g}$ for weanling rats, and $1.5-2 \mathrm{~g}$ for suckling rats.

Different amounts of the anion exchange cellulose solution were prepared for each age group (3 g DEAE-cellulose for adolescent, $2 \mathrm{~g}$ for weanling, and $1.5 \mathrm{~g}$ for suckling rats). This solution consisted of $3 \mathrm{~g}$ DEAE-cellulose, $7500 \mathrm{U} / 100 \mathrm{ml}$ heparin, $1 \mathrm{mM}$ dithiothreitol as final concentrations, $30 \mathrm{ml}$ isolation medium A (70 $\mathrm{mM}$ sucrose, $220 \mathrm{mM}$ mannitol, $2 \mathrm{mM}$ HEPES, $0.5 \mathrm{mM}$ EGTA, 0.1 mM PMSF, $0.37 \mathrm{~g} / 100 \mathrm{ml}$ BSA fatty acid-free fraction $\mathrm{V}, \mathrm{pH}$ 7.4).

The mucosal scrapings were stirred to an almost homogenate state with each amount of DEAE-cellulose solution. After standing $2 \mathrm{~min}, 40 \mathrm{ml}$ ( $30 \mathrm{ml}$ for weanling and suckling rats) isolation medium A was added to the suspension, stirred, and then homogenized by 6 strokes using a glass-Teflon homogenizer. The homogenate was then diluted with $50 \mathrm{ml}(40$ and $30 \mathrm{ml}$ for weanling and suckling rats, respectively) of isolation medium A and rehomogenized by 6 strokes using a glass-Teflon homogenizer. The homogenate was then centrifuged at $750 \times \mathrm{g}$ for 10 min at $4^{\circ} \mathrm{C}$ in a refrigerated centrifuge (Beckman, Model $\mathrm{J} 2-21$, Beckman Instruments, Fullerton, CA). The supernatant was then decanted and filtered through nylon cloth and recentrifuged at $10,000 \times \mathrm{g}$ for $7 \mathrm{~min}$. Crude mitochondrial pellet was obtained, which had a mucus layer above it. The layer of mucus was scraped off with a pipette.

The mitochondria-rich fraction was resuspended with $35 \mathrm{ml}$ of isolation medium $\mathrm{A}$ and recentrifuged at $14,000 \times \mathrm{g}$ for 7 min. The resultant pellet was resuspended with $35 \mathrm{ml}$ of isolation medium B (70 mM sucrose, $220 \mathrm{mM}$ mannitol, $2 \mathrm{mM}$ HEPES, $1.2 \mathrm{~g} / 100 \mathrm{ml} \mathrm{BSA}, \mathrm{pH} 7.2$ ) and then centrifuged at $14,000 \times \mathrm{g}$ for $10 \mathrm{~min}$. The resultant pellet was washed twice to remove BSA by $35 \mathrm{ml}$ of washing solution $(290 \mathrm{mM}$ mannitol, $2 \mathrm{mM}$ HEPES, $\mathrm{pH} 7.2$ ) using centrifugation at $14,000 \times \mathrm{g}$ for $7 \mathrm{~min}$. The mucus layer above the mitochondria-rich fraction was removed at each step. The final pellet was resuspended with 1.0$1.3 \mathrm{ml}$ washing solution for $\mathrm{Ca}^{++}$transport studies.

Transport measurement. $\mathrm{Ca}^{++}$influx and efflux were measured by a rapid filtration technique $(1,3,9)$. All experiments were performed at $25^{\circ} \mathrm{C}$. (The amount and composition of the incubation media for each experiment is described in the figure legends in "Results".)

$\mathrm{Ca}^{++}$influx and efflux reactions were stopped by a $1-\mathrm{ml}$ icecold stop solution consisting of $100 \mathrm{mM} \mathrm{MgCl}_{2}, 100 \mathrm{mM}$ mannitol, 20 mM HEPES, pH 7.2.

Separation of mitochondrial vesicles from the incubation solution were achieved by millipore filtration $(0.45-\mu \mathrm{m}$ pore size, Sartorius Filters. The filters were washed in a 5-ml ice-cold stop solution and placed in a scintillation vial. Radioactivity was determined in a liquid scintillation counter (Beckman Instruments, Palo Alto, CA) using Bray's solution (New England Nuclear Corp., Boston, MA).

Because the concentration of $\mathrm{Ca}^{++}$in the cytosol is in the range of 0.01-1 $\mathrm{mM}$, similar concentrations were used in the incubation media by using a Ca-EGTA buffer system (10). Protein determinations were performed by the method of Lowry et al. (11).

Purity and functional integrity of mitochondrial preparation. To characterize the purity of our preparation, transmission electronmicroscopic and enzyme marker studies were done. Vesicles were fixed in $2 \%$ glutaraldehyde for electronmicroscopic studies. Enzyme markers were determined in mucosal crude homogenate and vesicles. Cytochrome-c-oxidase, a marker for mitochondria, was measured by the method of Beaufay et al. (12). Leucine aminopeptidase, a marker for brush border membranes, was measured by a Sigma kit; $\mathrm{Na}^{+}-\mathrm{K}^{+}$-ATPase, a marker for basolateral membranes, by the method of Scharschmidt et al. (13); NADPH-cytochrome-c-reductase, a marker for endoplasmic reticulum, by the method of Beaufay et al. (12); galactosyl transferase, a marker for Golgi apparatus, by the method of Moore et al. (14). The functional integrity of the mitochondrial preparation was determined by oxygen consumption studies using an oxygen monitor (YSI biological oxygen monitor, Yellow Springs Instrument Co., Yellow Springs, OH), fitted with a clark-type oxygen electrode. Rates of oxygen consumption were calculated according to Chance and Williams (15). Succinate was used as a respiratory substrate. Rates of oxygen consumption were also monitored with the addition of ADP (state 3 ) and after depletion

Table 2. Oxidative phosphorylation by rat intestinal mitochondria*

\begin{tabular}{llcc}
\hline & Substrate & Respiratory control ratio & ADP/0 \\
\hline Adolescent & Succinate & $5.1 \pm 0.4$ & $1.8 \pm 0.1$ \\
Suckling & Succinate & $3.9 \pm 0.4$ & $1.9 \pm 0.2$ \\
\hline
\end{tabular}

* Concentration of succinate was $3.3 \mathrm{mM}$. ADP concentration was 50 $\mathrm{nmol} / \mathrm{mg}$ protein. Mitochondrial protein concentration was $5 \mathrm{mg} / \mathrm{ml}$. Mean \pm SEM represents three separate experiments. Each experiment was run in triplicate.

Table 1. Marker enzyme specific activities of mucosal homogenate and mitochondrial fraction*

\begin{tabular}{|c|c|c|c|c|}
\hline \multirow[b]{2}{*}{ Enzyme marker } & \multicolumn{2}{|c|}{ Adolescent } & \multicolumn{2}{|c|}{ Suckling } \\
\hline & $\begin{array}{l}\text { Mucosal } \\
\text { homogenate }\end{array}$ & Mitochondria & $\begin{array}{c}\text { Mucosal } \\
\text { homogenate }\end{array}$ & Mitochondria \\
\hline $\begin{array}{l}\text { Cytochrome } \mathrm{c} \text { oxidase ( } \mu \mathrm{mol} / \mathrm{mg} \text { pro- } \\
\text { tein } / \mathrm{min} \text { ) }\end{array}$ & $0.2 \pm 0.1$ & $2.4 \pm 0.2(12)$ & $0.1 \pm 0.1$ & $1.3 \pm 0.2(13)$ \\
\hline $\begin{array}{l}\text { NADPH cytochrome c-reductase } \\
(\mu \mathrm{mol} / \mathrm{mg} \text { protein } / \mathrm{min})\end{array}$ & $12.5 \pm 0.4$ & $18 \pm 0.5(1.4)$ & $10.8 \pm 0.2$ & $14.1 \pm 0.1(1.3)$ \\
\hline $\begin{array}{l}\text { Leucine aminopeptidase (mg } \beta \text {-naph- } \\
\text { thylamine/mg protein) }\end{array}$ & $0.68 \pm 0.1$ & $0.2 \pm 0.1(0.3)$ & $0.34 \pm 0.1$ & $0.1 \pm 0.1(0.3)$ \\
\hline $\begin{array}{l}\mathrm{Na}^{+}-\mathrm{K}^{+} \text {-ATPase }(\mu \mathrm{molPi} / \mathrm{h} / \mathrm{mg} \text { pro- } \\
\text { tein) }\end{array}$ & $1.5 \pm 0.1$ & $1 \pm 0.1(0.6)$ & $0.89 \pm 0.1$ & $0.5 \pm 0.1(0.5)$ \\
\hline Galactosyl transferase & $30 \pm 4$ & $10 \pm 2(0.3)$ & $20 \pm 3$ & $7 \pm 2(0.3)$ \\
\hline
\end{tabular}

* Values are mean \pm SEM of three separate experiments. Each experiment was run in triplicate. Numbers in parentheses indicate enrichment factors. 

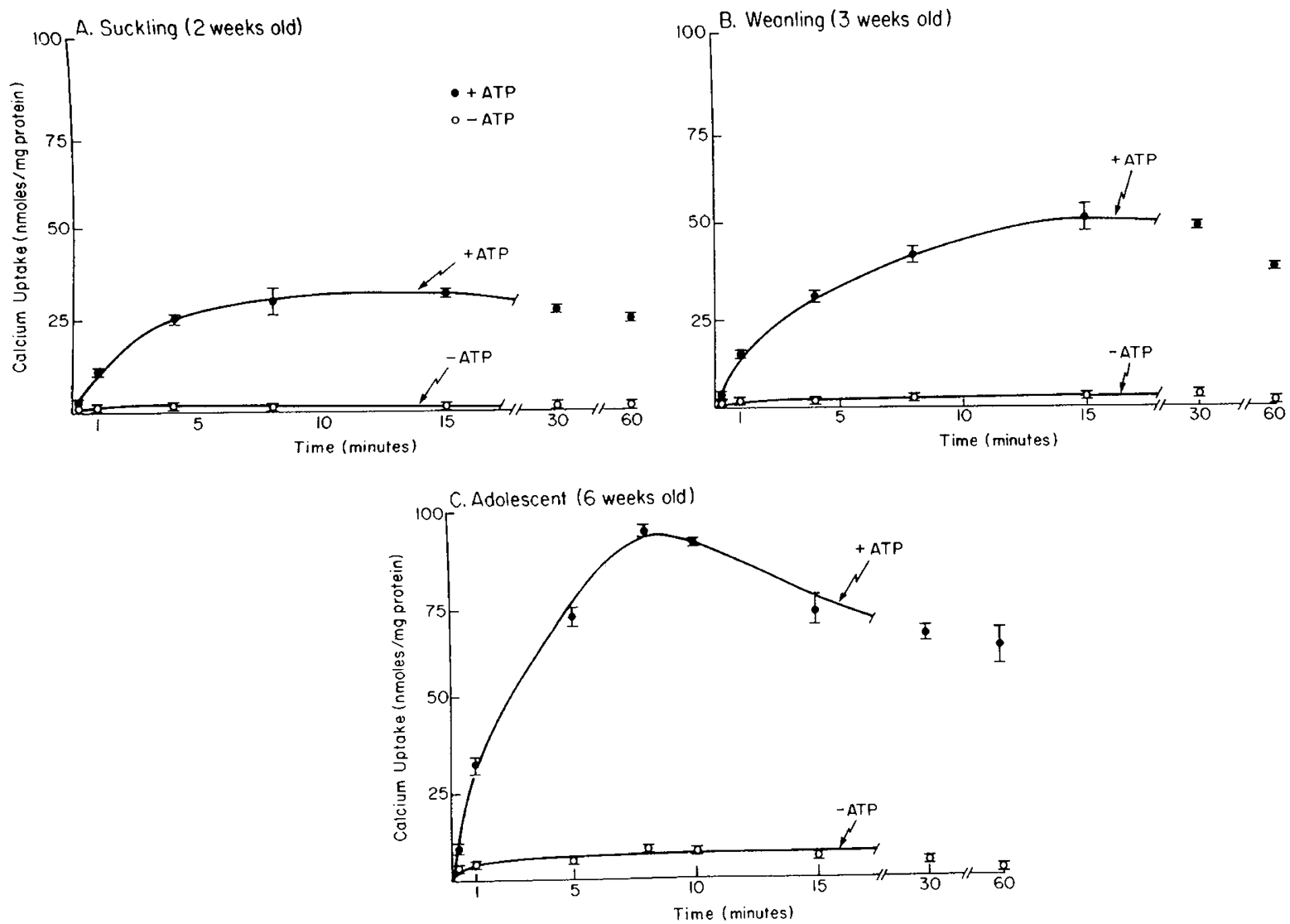

Fig. 1. Time course of calcium uptake in 2-wk-old $(A)$, 3-wk-old $(B)$, and 6-wk-old $(C)$ rats in the presence and absence of ATP. Mitochondria were prepared with $290 \mathrm{mM}$ mannitol, $2 \mathrm{mM}$ HEPES, pH 7.2. Incubation was started by the addition of mitochondria to a medium containing, in final concentration, either $130 \mathrm{mM} \mathrm{KCl}, 115 \mathrm{mM}$ mannitol, $20 \mathrm{mM}$ Tris $\mathrm{HCl}, 3 \mathrm{mM} \mathrm{ATP}-\mathrm{Mg}^{++}, 2 \mathrm{mM}$ succinate (K-salt), $0.6 \mathrm{mM}$ sucrose, buffer, $\mathrm{pH} 7.2,1 \mu \mathrm{M}$ calcium concentration and tracer ${ }^{45} \mathrm{Ca}$ or $130 \mathrm{mM} \mathrm{KCl}, 115 \mathrm{mM}$ mannitol, $20 \mathrm{mM}$ Tris $\mathrm{HCl}, 2 \mathrm{mM}$ succinate (K-salt), $0.6 \mathrm{mM}$ sucrose buffer, $\mathrm{pH} 7.2,1 \mu \mathrm{M}$ calcium concentration and tracer ${ }^{45} \mathrm{Ca}$. Reaction was stopped at $10 \mathrm{~s}, 1,4,(5), 8,(10), 15,30$ and $60 \mathrm{~min}$. Values are mean $\pm \mathrm{SE}$ of three separate experiments on different membrane preparations $(n=12)$.

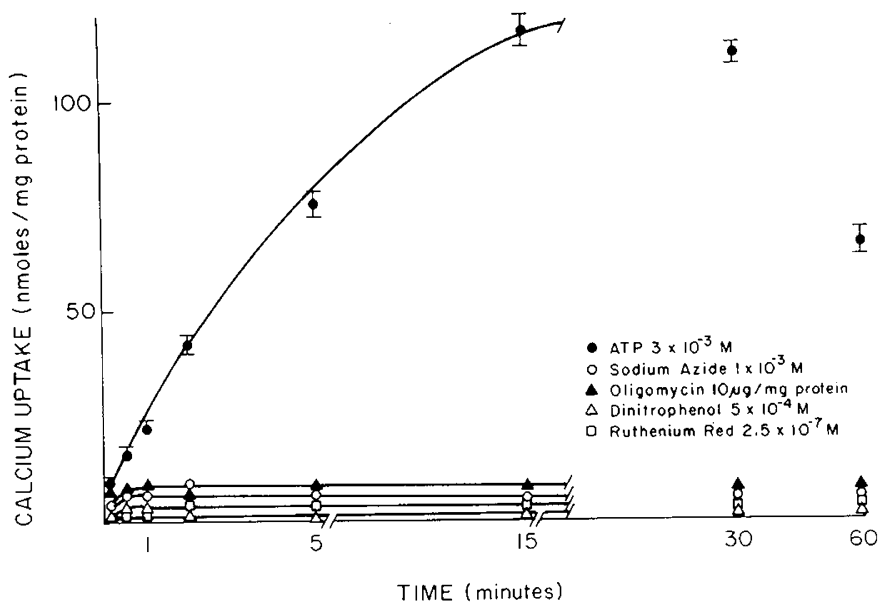

Fig. 2. Effect of oligomycin, ruthenium red, sodium azide and nitrophenol on calcium uptake. Mitochondria were prepared with $290 \mathrm{mM}$ mannitol, $2 \mathrm{mM}$ HEPES, $\mathrm{pH}$ 7.2. The reaction was started by the addition of $20 \mu \mathrm{l}$ of mitochondria vesicles to an incubation medium containing, in final concentration, $130 \mathrm{mM} \mathrm{KCl}, 115 \mathrm{mM}$ mannitol, 20 $\mathrm{mM}$ Tris $\mathrm{HCl}, 3 \mathrm{mM}$ ATP- $\mathrm{Mg}^{++}, 2 \mathrm{mM}$ succinate (K-salt), $0.6 \mathrm{mM}$ sucrose buffer, pH 7.2,1 $\mu \mathrm{M}$ calcium concentration and tracer ${ }^{45} \mathrm{Ca}$. uptake in the presence of ATP; $O$, uptake in the presence of sodium azide; $\boldsymbol{\Lambda}$, uptake in the presence of oligomycin $(10 \mu \mathrm{g} / \mathrm{mg}$ protein); $\Delta$, uptake in the presence of dinitrophenol; $\square$, uptake in the presence of ruthenium red $(0.25 \mathrm{mM})$. Values are mean $\pm \mathrm{SE}$ of three separate experiments on different membrane preparations $(n=12)$. of exogenous ADP (state 4). The respiratory control ratios state $3 /$ state 4 respiration, an indicator of mitochondrial functional integrity, were calculated as well as the ADP/O ratios. ATP hydrolysis was measured using a $\mathrm{pH}$ meter as described by Malms-strom and Carafoli (3). The hydrolysis of ATP at $\mathrm{pH} 7.0$ is described by the following equation:

$$
\mathrm{ATP}+\mathrm{H}_{2} \mathrm{O} \rightarrow \mathrm{ADP}+\mathrm{Pi}+0.75 \mathrm{H}^{+}
$$

Therefore, the formation of $\mathrm{H}^{+}$reflects rates of ATP hydrolysis. Mitochondrial preparations from suckling and adolescent rats were placed in a cuvette at pH 7.0. ATP $(3 \mathrm{mM}, \mathrm{pH} 7.0)$ was then added. After $1 \mathrm{~min}$, the $\mathrm{pH}$ was recorded. We then added $100 \mathrm{nmol}$ of calcium, and the $\mathrm{pH}$ was recorded again. Repeated addition of $\mathrm{CaCl}_{2}$ was continued until no change in $\mathrm{pH}$ was noted. The amount of ATP hydrolyzed was calculated from the above equation.

Statistical analysis. All values were expressed graphically as the mean \pm 1 SEM. Student's $t$ test was used to evaluate the statistical significance of differences between the groups. A probability value $(p<0.05)$ was considered statistically significant.

\section{RESULTS}

Determination of binding component. The uptake of $\mathrm{Ca}^{++}$by mitochondria represents both binding to the outer mitochondrial membrane and the inner membrane (intermembrane space) as well as transport into the inner membrane matrix. The binding component was determined by using ${ }^{3} \mathrm{H}$-sucrose $(0.5 \mu \mathrm{Ci} /$ tube $)$, which penetrates the outer membrane but is excluded from the intramitochondrial matrix volume. The radioactivity content 
was determined in the presence of ${ }^{45} \mathrm{Ca}^{++}(0.25 \mu \mathrm{Ci} /$ tube $)$ and 3 $\mathrm{mM}$ ATP at 60 min by dual isotope counting $(1,16,17)$. The extramitochondrial volume was $14.9 \pm 1.03 \%$ as measured by ${ }^{3} \mathrm{H}$-sucrose in five separate experiments. The amount of accumulated $\mathrm{Ca}^{++}$into the sucrose impermeable space, namely, matrix, was calculated by multiplying total $\mathrm{Ca}^{++}$uptake by $85.1 \%$.

Purity of mitochondrial preparation. Highly enriched energized mitochondria were obtained from all age groups as determined by transmission electronmicroscopy. Table 1 depicts the specific activities of marker enzymes in crude mucosal homogenate and mitochondrial preparations. As seen in Table 1, an enriched mitochondrial preparation is evident by the 12-fold enrichment in cytochrome-c-oxidase. There is minimal contamination with endoplasmic reticulum; marker enzymes for brush borders, basolateral membranes, and Golgi apparatus were impoverished. Table 2 depicts oxidative phosphorylation by mitochondrial preparation. As seen, respiratory control ratios were $5.1 \pm 0.4$ and $3.9 \pm 0.4$ in both adolescent and suckling rat mitochondria. Moreover, the $\mathrm{ADP} / \mathrm{O}$ ratio was $1.80 \pm 0.1$ and $1.9 \pm 0.2$ for adolescent and suckling rats, respectively, suggesting functional mitochondria.

Rates of ATP hydrolysis were $15.5 \pm 1.5$ and $2.9 \pm 0.3 \mathrm{nmol}$ ATP hydrolyzed $/ \mathrm{mg}$ protein $/ \mathrm{min}$ for adolescent and suckling rats, respectively $(p<0.001)$.

$\mathrm{Ca}^{++}$uptake with time. A 20- $\mu$ l sample of mitochondrial suspension $(10 \mathrm{mg} / \mathrm{ml})$ was diluted in a $60-\mu l$ incubation media containing, in final concentration, $130 \mathrm{mM} \mathrm{KCl}, 115 \mathrm{mM}$ mannitol, $20 \mathrm{mM}$ Tris $\mathrm{HCl}, 2 \mathrm{mM}$ succinate (K-salt), $0.6 \mathrm{mM}$ sucrose, $3 \mathrm{mM}$ ATP- $\mathrm{Mg}^{++}, \mathrm{pH} 7.2$, and $20 \mu \mathrm{l}$ of Ca-EGTA solution (final free $\mathrm{Ca}^{++}$concentration $\left.1 \mu \mathrm{M}\right)$ and ${ }^{45} \mathrm{Ca}(0.25 \mu \mathrm{Ci} /$ tube). Figure 1 shows $\mathrm{Ca}^{++}$uptake in the presence and absence of $3 \mathrm{mM}$ ATP with time at all age groups. $\mathrm{Ca}^{++}$uptake in the presence of 3 mM ATP was significantly greater than in the absence of ATP $(p<0.05-0.001)$. The accumulation of $\mathrm{Ca}^{++}$in adolescent rats was inhibited completely by $0.25 \mathrm{mM}$ ruthenium red, $10 \mu \mathrm{g} / \mathrm{mg}$ protein oligomycin, $0.5 \mathrm{mM}$ dinitrophenol or $1 \mathrm{mM}$ sodium azide (Fig. 2). In the presence of succinate, oligomycin inhibited calcium uptake only by $44 \%$. Similar inhibition was noted for other age groups (data not shown).

Kinetics of $\mathrm{Ca}^{++}$uptake with age. First, initial uptake rate was determined at $2,4,8,12,16,20,30$, and $60 \mathrm{~s}$. Figure 3 shows $\mathrm{Ca}^{++}$uptake in the presence of $3 \mathrm{mM}$ ATP up to $60 \mathrm{~s}$ in adolescent rats. Initial rate uptake was linear up to $30 \mathrm{~s}$. Therefore, kinetic studies were done at $10 \mathrm{~s}$, well within the linear line of uptake. $\mathrm{Ca}^{++}$uptake was determined using different $\mathrm{Ca}^{++}$ concentrations $(0.01$ to $10 \mu \mathrm{M})$. These concentrations were achieved using a Ca-EGTA buffer system (10). Km and $\mathrm{V}_{\max }$ were calculated using a computerized model of the MichaelisMenten kinetics (18).

Figure 4 depicts the kinetic parameters for $\mathrm{Ca}^{++}$uptake in mitochondria of jejunum at all age groups. $\mathrm{Km}$ values were 0.84 $\pm 0.11,0.65 \pm 0.17$, and $0.57 \pm 0.03 \mu \mathrm{M}$, and $\mathrm{V}_{\max }$ values were $1.83 \pm 0.07,3.63 \pm 0.26$, and $14.15 \pm 0.21 \mathrm{nmol} / \mathrm{mg}$ protein/ $10 \mathrm{~s}$ for suckling, weanling, and adolescent rats, respectively. Therefore, the affinity and capacity of the mitochondrial calcium transport system increases with advancing age.

Mitochondrial calcium efflux. The energized mitochondria possess a $\mathrm{Ca}^{++}$efflux system which occurs by separate and independent pathways $(1,4,19)$. A sodium-independent pathway representing a passive calcium-proton exchanger and a sodiumdependent pathway representing a $\mathrm{Ca}^{++} / \mathrm{Na}^{+}$exchange against electrochemical gradient has been described in many organs, such as the liver and heart $(16,20-26) . \mathrm{Ca}^{++}$efflux in intestinal mitochondria is poorly understood in comparison with mitochondria from other sources.

We therefore defined whether a $\mathrm{Ca}^{++}$efflux from intestinal mitochondria was present using the following experiments. Mitochondria were incubated in a media containing $290 \mathrm{mM}$ mannitol, $2 \mathrm{mM}$ HEPES, $3 \mathrm{mM}$ ATP-Tris, $2 \mathrm{mM}$ succinate (K-

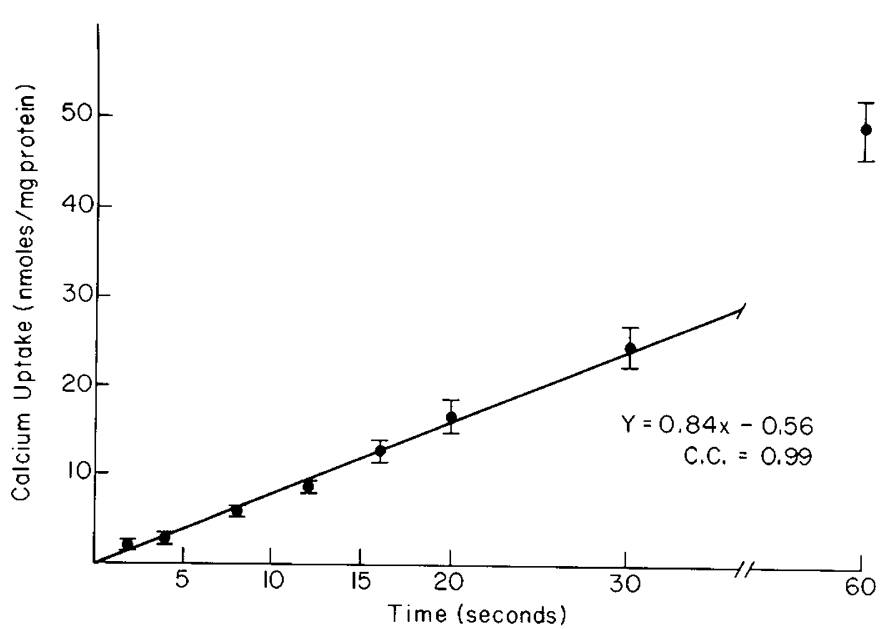

Fig. 3. Initial rate uptake of calcium. Mitochondria were prepared with $290 \mathrm{mM}$ mannitol, $2 \mathrm{mM}$ HEPES, pH 7.2. The reaction was started by the addition of $20 \mu \mathrm{l}$ of mitochondria vesicles to an incubation medium containing, in final concentration, $130 \mathrm{mM} \mathrm{KCl}, 115 \mathrm{mM}$ mannitol, $20 \mathrm{mM}$ Tris $\mathrm{HCl}, 3 \mathrm{mM}$ ATP- $\mathrm{Mg}^{++}, 2 \mathrm{mM}$ succinate (K-salt), $0.6 \mathrm{mM}$ sucrose buffer, $\mathrm{pH} 7.2,1 \mu \mathrm{M}$ calcium concentration and tracer ${ }^{45} \mathrm{Ca}$. Calcium uptake was determined with time up to $60 \mathrm{~s}$. The uptake appears linear up to $30 \mathrm{~s}$. Values are mean $\pm \mathrm{SE}$ of two separate experiments on different membrane preparations $(n=6)$.

salt), $\mathrm{pH} 7.2$, and $1 \mu \mathrm{M}$ Ca-EGTA solution and ${ }^{45} \mathrm{Ca}$ for $10 \mathrm{~min}$ at $25^{\circ} \mathrm{C}$. Ruthenium red $(2 \mu \mathrm{M})$ was then added to inhibit any further uptake. After $3 \mathrm{~min}, \mathrm{Ca}^{++}$efflux was induced by the introduction of $20 \mathrm{mM} \mathrm{NaCl}$ at specific time points: 0 and $10 \mathrm{~s}$ and 1, 2, 5, and $30 \mathrm{~min}$. These samples were obtained and pipetted immediately into a stop solution containing $100 \mathrm{mM}$ $\mathrm{MgCl}_{2}, 20 \mathrm{mM}$ HEPES, $100 \mathrm{mM}$ mannitol, $\mathrm{pH} 7.2$, then filtered over Sartorius filters on a millipore filtration system and washed with the same ice-cold stop solution.

Figure 5 depicts the time course of $\mathrm{Ca}^{++}$efflux from mitochondria of jejunum in adolescent and suckling rats. $\mathrm{Ca}^{++}$efflux rates were compared in the presence of ruthenium red in $\mathrm{Na}^{+}$ media containing $20 \mathrm{mM} \mathrm{NaCl}, 260 \mathrm{mM}$ mannitol, $15 \mathrm{mM}$ HEPES, pH 7.2 and in $\mathrm{Na}^{+}$-free media containing $20 \mathrm{mM} \mathrm{KCl}$, $260 \mathrm{mM}$ mannitol, $15 \mathrm{mM}$ HEPES, pH 7.2. As seen in Figure $5, \mathrm{Na}^{+}$-induced $\mathrm{Ca}^{++}$efflux was obtained in both age groups. The relationship between $\mathrm{Ca}^{++}$efflux and the $\mathrm{Na}^{+}$concentration $(0-30 \mathrm{mM})$ showed that the $\mathrm{Na}^{+}$concentration required for half maximal velocity was $10.3 \pm 2.2 \mathrm{mM}$, and maximal velocity for $\mathrm{Na}^{+}$induced $\mathrm{Ca}^{++}$efflux was $5.0 \pm 0.6 \mathrm{nmol} / \mathrm{mg}$ protein $/ 10 \mathrm{~min}$ (Fig. 6).

Figure 7 depicts the rate of $\mathrm{Ca}^{++}$efflux after addition of FCCP $(10 \mu \mathrm{M})$ to determine the effect of membrane potential on $\mathrm{Ca}^{++}$ efflux pathway (25). An extremely rapid $\mathrm{Ca}^{++}$efflux was obtained with FCCP compared to no FCCP conditions. In a separate experiment, the effect of $1 \mu \mathrm{M}$ inositol 1,4,5 triphosphate was tested on mitochondrial $\mathrm{Ca}^{++}$efflux. No effect was noted.

\section{DISCUSSION}

Because the intestine is the main organ responsible for the transport of calcium and because there is an inverse relationship between calcium absorption and age, we hypothesized that intestinal mitochondria have a well-developed system involved in cytosolic calcium regulation during early life.

Calcium transport through the intestinal cell involves a series of steps, entry at the brush border membrane, movement inside the cell and possible interaction with major organelles, e.g. endoplasmic reticulum, the Golgi apparatus, mitochondria, and extrusion from the cell.

Although each of these steps has been studied with the aid of 
isolated organelles, the role of mitochondria in rat intestine has not been studied, partly because of the difficulty in isolating a pure mitochondrial preparation from rat small intestine. Rat intestine has a large number of mucus-secreting goblet cells (7). Therefore, it is essential to remove adherent mucus during the preparation. Anion exchange cellulose was used to remove mucus. EGTA solution was used in the preparation to prevent calcium loading of mitochondria during preparation (21).

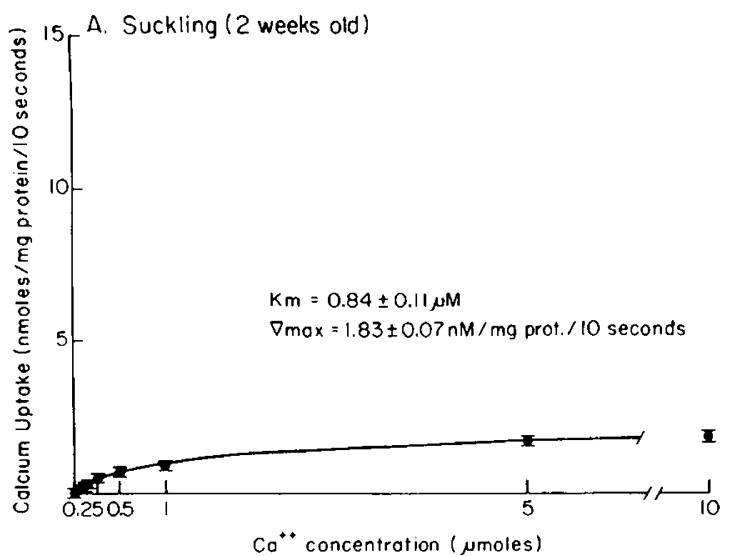

Using these methods, we obtained a highly enriched energized mitochondria. The extramitochondrial volume as measured by ${ }^{3} \mathrm{H}$-sucrose was $14.9 \%$. We used three groups of rats: suckling ( 15 days old), weanling ( 21 days old), and adolescent (42 days old) rats. As seen in Figures 1 and $2, \mathrm{Ca}^{++}$uptake was ATPdependent at all age groups. Maximal $\mathrm{Ca}^{++}$uptake in the presence of $3 \mathrm{mM}$ ATP and $2 \mathrm{mM}$ succinate at $1 \mu \mathrm{M} \mathrm{Ca}^{++}$concentration was obtained at 8-15 min. Maximal $\mathrm{Ca}^{++}$uptake in

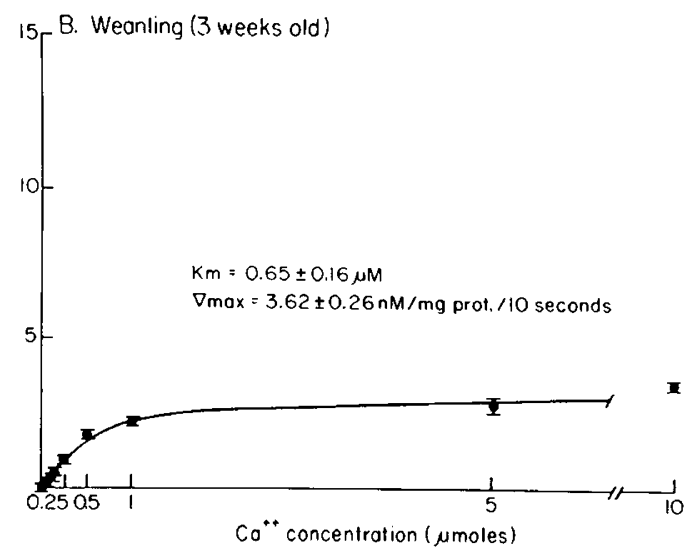

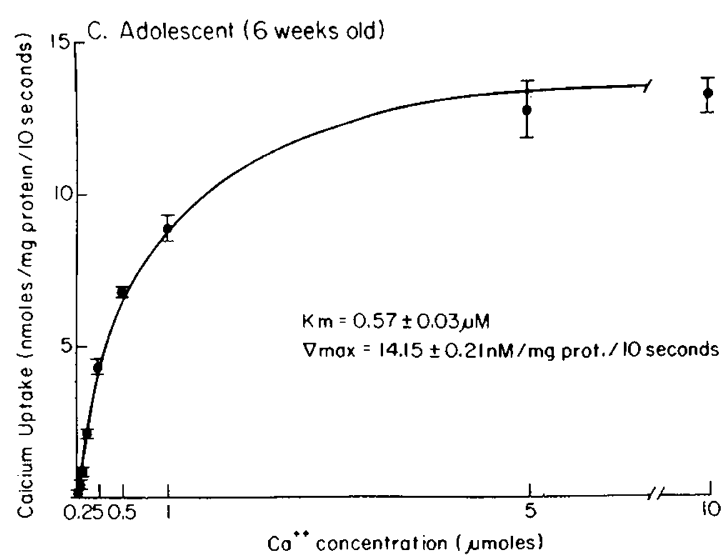

Fig. 4. Kinetics of calcium uptake in 2-wk-old $(A)$, 3-wk-old $(B)$, and 6-wk-old $(C)$ rats. Mitochondria were prepared with $290 \mathrm{mM}$ mannitol, 2 mM HEPES, pH 7.2 and incubated in a medium containing, in final concentration, $130 \mathrm{mM} \mathrm{KCl}, 115 \mathrm{mM}$ mannitol, $20 \mathrm{mM} \mathrm{Tris} \mathrm{HCl}, 3 \mathrm{mM}$ ATP- $\mathrm{Mg}^{++}, 2 \mathrm{mM}$ succinate (K-salt), $0.6 \mathrm{mM}$ sucrose buffer, $\mathrm{pH} 7.2$, different calcium concentrations $0.01-10 \mu \mathrm{M}$ and tracer ${ }^{45} \mathrm{Ca}$. Calcium uptake was determined at $10 \mathrm{~s}$. Kinetic parameters were obtained for the mediated component using a computerized model of the Michaelis-Menten kinetics. Values are mean $\pm \mathrm{SE}$ of three separate experiments on different membrane preparations $(n=12)$.
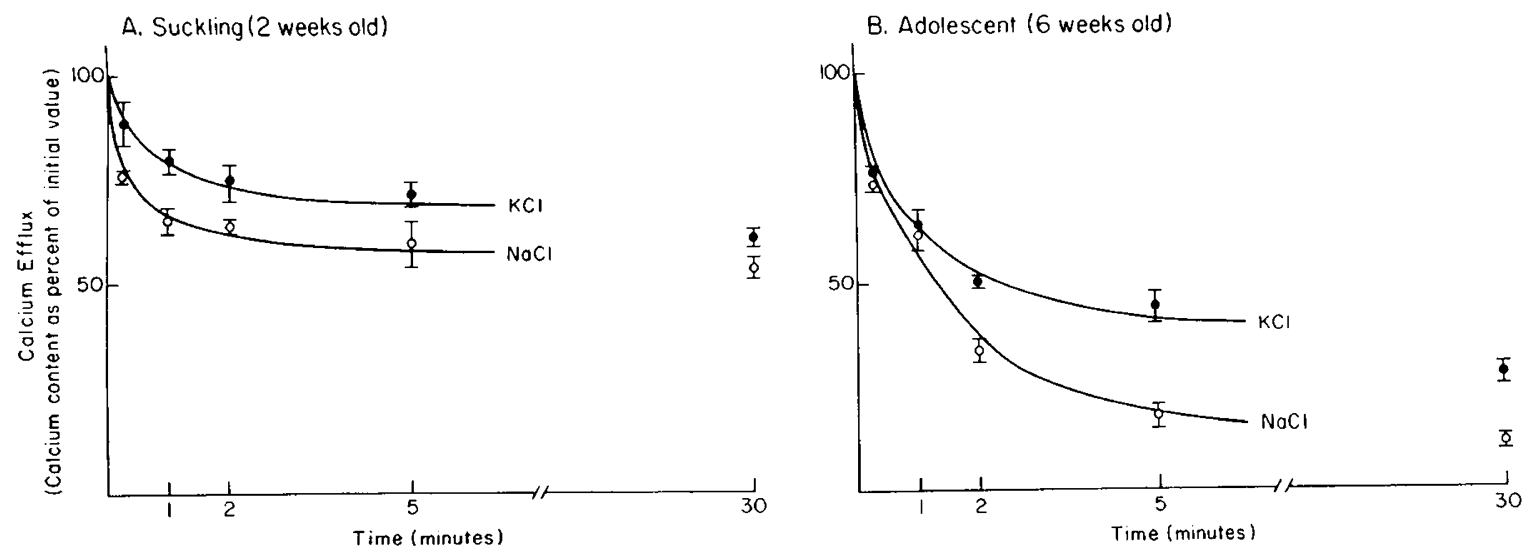

Fig. 5. Time course of calcium efflux in 2-wk-old $(A)$ and 6-wk-old $(B)$ rats. Mitochondria were incubated in a medium containing $290 \mathrm{mM}$ mannitol, $2 \mathrm{mM}$ HEPES, $3 \mathrm{mM}$ ATP-Tris, $2 \mathrm{mM}$ succinate (K-salt), buffer pH 7.2, and $1 \mu \mathrm{M}$ calcium concentration and tracer ${ }^{45} \mathrm{Ca}$ for $10 \mathrm{~min}$. Ruthenium red $(2 \mu \mathrm{M})$ was then added. $\mathrm{Ca}^{++}$efflux was then determined with time by diluting the mitochondria in a medium containing either 20 $\mathrm{mM} \mathrm{NaCl}, 260 \mathrm{mM}$ mannitol, $15 \mathrm{mM}$ HEPES buffer, $\mathrm{pH} 7.2(\mathrm{O})$ or $20 \mathrm{mM} \mathrm{KCl}, 260 \mathrm{mM}$ mannitol, $15 \mathrm{mM}$ HEPES buffer, pH 7.2 (•). Values are mean $\pm \mathrm{SE}$ of three separate experiments on different membrane preparations $(n=12)$. 


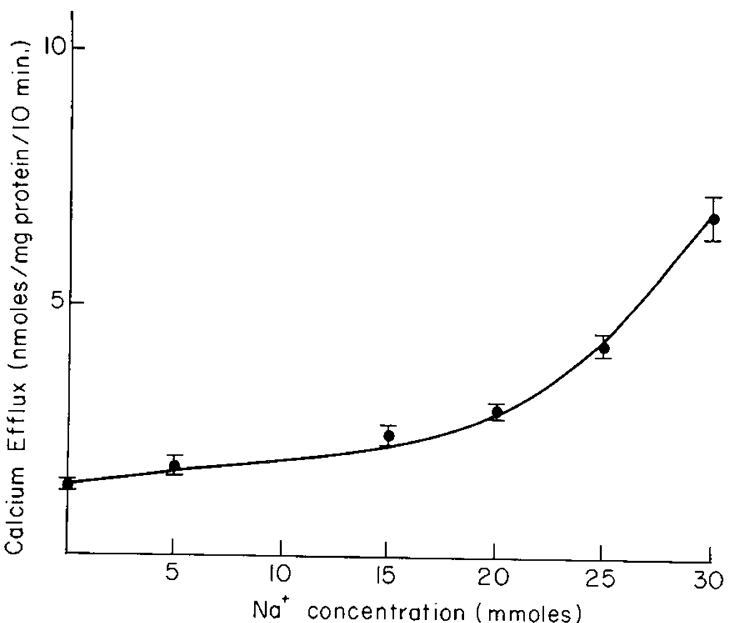

Fig. 6. The effect of $\mathrm{Na}^{+}$concentration on the rate of ruthenium redinduced $\mathrm{Ca}^{++}$efflux. Mitochondria were incubated in a medium containing $290 \mathrm{mM}$ mannitol, $2 \mathrm{mM}$ HEPES, $3 \mathrm{mM}$ ATP-Tris, $2 \mathrm{mM}$ succinate (K-salt) buffer, pH 7.2, and $1 \mu \mathrm{M}$ calcium concentration and tracer ${ }^{45} \mathrm{Ca}$ for $10 \mathrm{~min}$. Ruthenium red $(2 \mu \mathrm{M})$ was then added. $\mathrm{Ca}^{++}$efflux was then determined with time by diluting the mitochondria in a medium containing different $\mathrm{Na}^{+}$concentrations $(0-30 \mathrm{mM})$. Values are mean $\pm \mathrm{SE}$ of three separate experiments on different membrane preparations $(n=$ 12).

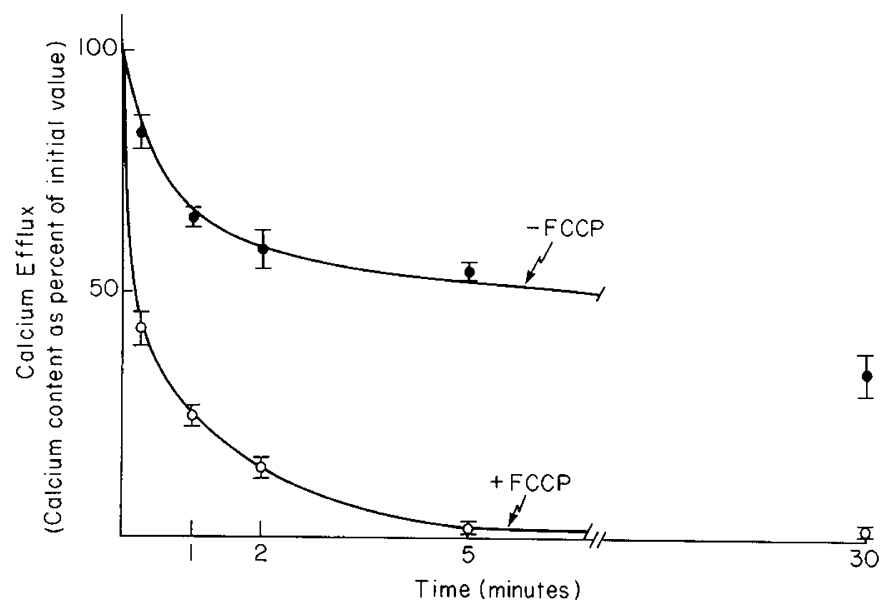

Fig. 7. The effect of membrane potential on the rate of $\mathrm{Ca}^{++}$efflux. Mitochondria were incubated in a medium containing $290 \mathrm{mM}$ mannitol, 2 mM HEPES, 2 mM ATP-Tris, $2 \mathrm{mM}$ succinate (K-salt) buffer, $\mathrm{pH}$ 7.2 and $1 \mu \mathrm{M}$ calcium concentration and tracer ${ }^{45} \mathrm{Ca}$ for $10 \mathrm{~min}$. Ruthenium red $(2 \mu \mathrm{M})$ was then added. $\mathrm{Ca}^{++}$efflux was then determined with time by diluting the mitochondria in incubation solution containing buffer $20 \mathrm{mM} \mathrm{KCl}, 260 \mathrm{mM}$ mannitol, $15 \mathrm{mM}$ HEPES, pH 7.2 with 10 $\mu \mathrm{M}$ FCCP (O), or without FCCP (๑). Values are mean \pm SE of three separate experiments on different membrane preparations $(n=12)$.

adolescent rats was 2-3 times greater than corresponding values in weanling and suckling rats. $\mathrm{Ca}^{++}$uptake at all age groups in the same media was partly blocked by $10 \mu \mathrm{g} / \mathrm{mg}$ protein of oligomycin, an inhibitor of mitochondrial ATPase when succinate was present in the incubation media (27), indicating that exogenous ATP provides part of the energy required for calcium uptake. Ruthenium red $(0.25 \mathrm{mM})$, a specific inhibitor of mitochondrial $\mathrm{Ca}^{++}$accumulation, completely inhibited $\mathrm{Ca}^{++}$uptake (28). Similar results were obtained with chick intestinal mitochondria (5) and with other mitochondrial calcium transport systems in the liver and heart $(2,29)$, and dinitrophenol and sodium azide also inhibited $\mathrm{Ca}^{++}$uptake by the mitochondria through metabolic inhibition. The kinetic parameters show a characteristic developmental pattern in regard to the affinity and capacity of the calcium transport system. Both the affinity and capacity increase with advancing age. The changes in $V_{\max }$ most likely reflects greater rates of ATP hydrolysis noted in adolescent rats compared to suckling rats, thus providing greater uptake of calcium.

Calcium efflux from the mitochondria occurred by a $\mathrm{Na}^{+}-$ dependent pathway, indicating $\mathrm{Ca}^{++} / \mathrm{Na}^{+}$exchange as evident by greater $\mathrm{Ca}^{++}$efflux in the presence of $\mathrm{Na}^{+}$compared to $\mathrm{K}^{+}$in the incubation media. The concentration of $\mathrm{Na}^{+}$required for half maximal velocity was $10.3 \pm 2.2 \mathrm{mM}$, and the maximal velocity for $\mathrm{Na}^{+}$-induced $\mathrm{Ca}^{++}$efflux was $5.0 \pm 0.6 \mathrm{nmol} / \mathrm{mg}$ protein/10 min. These kinetic parameters are similar to those reported for the mitochondria of rat brain and adrenal cortex (6). A sodium-independent pathway regulated by the membrane potential across the mitochondria is also present because the addition of FCCP, which dissipates the membrane potential across the mitochondria, resulted in rapid $\mathrm{Ca}^{++}$efflux independent of the presence of $\mathrm{Na}^{+}$. This finding is similar to that described for liver mitochondria (25). Inositol 1,4,5 triphosphate had no effect on calcium efflux. Our results suggest that the mitochondria of suckling and weanling enterocytes possess a highly developed calcium transport system which is similar in character to other mitochondria of such organs as the heart (2), liver (25), and kidney (17); however, this calcium transport system exhibits maturational changes in regard to its kinetic parameters.

\section{REFERENCES}

1. Crompton M, Carafoli E 1979 The measurement of $\mathrm{Ca}^{2+}$ movements in mitochondria. Methods Enzymol 56:338-352

2. Crompton M, Heid I 1978 The cycling of calcium, sodium, and protons across the inner membrane of cardiac mitochondria. Eur J Biochem 91:599-608

3. Malmstrom K, Carafoli E 1979 Calcium transport in mitochondria. Membrane Biochemistry. Springer-Verlag, New York, pp 103-112

4. Nicholls DG, Akerman K 1982 Mitochondria calcium transport. Biochim Biophys Acta 683:57-88

5. Bikle D, Wayne-Askew E, Zolock DT, Morrissey RL, Herman RH 1980 Calcium accumulation by chick intestinal mitochondrial regulation by vita$\min \mathrm{D}_{3}$ and 1,25-dihydroxyvitamin $\mathrm{D}_{3}$. Biochim Biophys Acta 598:561-574

6. Crompton M, Moser R, Ludi H, Carafoli E 1978 The interrelations between the transport of sodium and calcium in mitochondria of various mammalian tissues. Eur J Biochem 82:25-31

7. Hulsmann WC, Vandenberg JWO, DeJonge HR 1974 Isolation of intestinal mucosa cells. Methods Enzymol 32:665-673

8. Lawrence CB, Davies NT 1986 A novel, simple and rapid method for the isolation of mitochondria which exhibit respiratory control, from rat small intestinal mucosa. Biochim Biophys Acta 848:35-40

9. Hopfer U, Nelson K, Perrotto J, Isselbacher KJ 1973 Glucose transport in isolated brush border membrane from rat small intestine. J Biol Chem 248:25-32

10. Pershadsingh HA, McDonald JM 1980 A high affinity calcium-stimulated magnesium-dependent adenosine triphosphatase in rat adipocyte plasma membranes. J Biol Chem 255:4087-4093

11. Lowry OH, Rosebrough NJ, Lewisfarr A, Randall RJ 1951 Protein measurement with the folin phenol reagent. J Biol Chem 193:265-275

12. Beaufay H, Costesec AA, Feytmans E, Wibo M, Robbi M, Berthet J 1974 Analytical study of microsomes and isolated subcellular membranes from rat liver. J Cell Biol 61:188-200

13. Scharschmidt BF, Keeffe EB, Blankenship NM, Ockner RK 1979 Validation of a recording spectrophotometric method for measurement of membraneassociated $\mathrm{Mg}^{++}$and $\mathrm{Na}^{+} \mathrm{K}^{+}$-ATPase activity. J Lab Clin Med 93:790-799

14. Moore DJ, Merlin LM, Keenan TW 1969 Localization of glycosyl transferase activities in a Golgi apparatus-rich fraction isolated from rat liver. Biochem Biophys Res Commun 37:813-819

15. Chance B, Williams GR 1955 A simple and rapid assay of oxidative phosphorylation. Nature 175:1120-1121

16. Crompton M, Capano M, Carafoli E 1976 The sodium-induced efflux of calcium from heart mitochondria. Eur J Biochem 69:453-462

17. Haworth RA, Hunter DR, Berkoff HA $1980 \mathrm{Na}^{+}$releases $\mathrm{Ca}^{2+}$ from liver, kidney, and lung mitochondria. FEBS Lett 110:216-218

18. Vaughn WK, Neal RA, Anderson AJ 1976 Computer estimation of the parameters of the sigmoidal kinetic model. Comput Biol Med 6:1-7

19. Denton RM, McCormack JG $1985 \mathrm{Ca}^{2+}$ transport by mammalian mitochondria and its role in hormone action. Am J Physiol 249:E543-E554

20. Fiskum G, Lehninger AL 1979 Regulated release of $\mathrm{Ca}^{2+}$ from respiring mitochondria by $\mathrm{Ca}^{2+} / 2 \mathrm{H}^{+}$antiport. J Biol Chem 254:6236-6239

21. Masola B, Evered DF 1984 Preparation of rat enterocyte mitochondria. Biochem J 218:441-447 
22. Heffron JA, Harris EJ 1981 Stimulation of calcium-ion efflux from liver mitochondria by sodium ions and its response to ADP and energy state. Biochem J 194:925-929

23. Wingrove DE, Gunter TE 1986 Kinetics of mitochondria calcium transport: II: a kinetic description of the sodium-dependent calcium efflux mechanism of liver mitochondria and inhibition by ruthenium red and by tetraphenylphosphonium. J Biol Chem 261:15166-15171

24. Wingrove DE, Gunter TE 1986 Kinetics of mitochondria calcium transport: I. characteristics of the sodium-independent calcium efflux mechanism of liver mitochondria. J Biol Chem 261:15159-15165

25. Zoccarato F, Nicholls D 1982 The role of phosphate in the regulation of the independent calcium-efflux pathway of liver mitochondria. Eur J Biochem
$127: 333-338$

26. Nicholls DG, Scott ID 1980 The regulation of brain mitochondrial calciumion transport. Biochem J 186:833-839

27. Lardy HA, Johnson D, McMurray WC 1958 Antibiotics as tools for metabolic studies: a survey of toxic antibiotics in respiratory, phosphorylative and glycolytic systems. Arch Biochem Biophys 78:587-597

28. Vasington FD, Gazzotti P, Tiozzo R, Carafoli E 1972 The effects of ruthenium red on energy metabolism in mitochondria. In: Biochemistry and Biophysics of Mitochondrial Membranes. Academic Press, New York, pp 215-228

29. Heaton GM, Nicholls DG 1976 The calcium conductance of the inner membrane of rat liver mitochondria and the determination of the calcium electrochemical gradient. Biochem J 156:635-646 